EMILIA GRZESIAK

ORCID 0000-0001-5667-4600

Uniwersytet im. Adama Mickiewicza

$w$ Poznaniu

\title{
SPOŁECZNE KONSTRUOWANIE RYTUAŁÓW I SYMBOLI AKADEMICKICH
}

\begin{abstract}
AвSTRACt. Grzesiak Emilia, Społeczne konstruowanie rytuałów i symboli akademickich [Social Construction of Academic Rituals and Symbols]. Studia Edukacyjne nr 53, 2019, Poznań 2019, pp. 27-39. Adam Mickiewicz University Press. ISSN 1233-6688. DOI: 10.14746/se.2019.53.2

Rites and ceremonies are very important in university reality. They are extremely important for maintaining the continuity of academic values and highlighting the rank of certain events, which is particularly visible during various academic ceremonies.

This article will be devoted to academic rituals, ceremonies and symbols in the context of their social meaning and values. I refer this issue to other dimensions of socio-cultural reality (including ceremonial court practices), I will look for similarities, explaining their significance and roles. I will try to justify how - regarding their long history and tradition - we can understand them in the 21st century.
\end{abstract}

Key words: rites, ceremonies, regalia, university, society, socio-cultural reality, tradition

Niniejszy artykuł poświęcony jest rytuałom, ceremoniom i symbolom akademickim w kontekście ich społecznego znaczenia oraz wartości. Pozwolę sobie na odniesienie tego zagadnienia do innych wymiarów rzeczywistości społecznej (m.in. ceremonialnych praktyk sądowych), poszukam podobieństw, wyjaśniających, jakie znaczenie i jaką rolę pełnią one w istocie oraz postaram się uzasadnić, jak - biorąc pod uwagę ich długą historię oraz tradycję - możemy rozumieć je w XXI wieku.

Obrzędy i ceremonie stanowią ważny element rzeczywistości uniwersyteckiej, bowiem kolory, przedmioty i regalia akademickie (te ostatnie rozumiane jako element materialno-symboliczny wchodzący w skład rytuałów akademickich) są mocno zakorzenione $\mathrm{w}$ środowisku uniwersyteckim już od kilkuset lat. Istotna jest tutaj tradycja i permanencja symboli, obowiązu- 
jących już od czasów średniowiecza ${ }^{1}$. Są one niezwykle ważne dla zachowania ciągłości akademickich wartości i podkreślenia rangi pewnych wydarzeń, co w sposób szczególny widoczne jest podczas różnorodnych akademickich uroczystości. Jedną z nich jest uroczystość nadawania stopni i tytułów naukowych. To właśnie podczas tego wydarzenia na pierwszy plan wysuwa się tradycja, o czym świadczy chociażby precyzyjnie przygotowana i dopracowana w najdrobniejszych szczegółach ceremonia, podczas której mają miejsce określone rytuały bądź obrzędy, charakterystyczne dla danego uniwersytetu, szkoły wyższej, czy nawet kierunku studiów ${ }^{2}$. W tym miejscu warto wspomnieć, iż

niezwykłą rangą i wyjątkowością - biorąc pod uwagę charakter i przebieg wydarzenia - wyróżnia się np. uroczystość nadania doktoratu honorowego - doctor honoris causa, przyznawanego za szczególne osiągnięcia naukowe, ale również za znaczący wkład jednostki w życie społeczne i uniwersyteckie ${ }^{3}$.

Wydarzenie to stanowi przykład niezwykle prestiżowej uroczystości będącej swoistym wyrazem potwierdzenia wysokiego statusu naukowego osoby dostępującej tego zaszczytu.

W wielu krajach obrzędy, ceremonie i związane z nimi akademickie symbole stanowią wierne odtworzenie wydarzeń z czasów średniowiecznych (przykładem może być Uniwersytet Oxfordzki, gdzie toga noszona obecnie na uroczystościach akademickich jest bardzo podobna do tej noszonej w średniowieczu - ostatnie poprawki miały miejsce w XVI wieku) ${ }^{4}$. Należy jednak zwrócić uwagę, iż niekiedy dopuszcza się pewnych zmian i modyfikacji w zakresie elementów stroju czy przebiegu ceremonii akademickich, mających przystosować je do warunków lokalnych (przykładem są kraje europejskie), jednak jedynie pod warunkiem, że będą one uzasadnione, a ostateczny wygląd stroju pozostanie wierny duchowi tradycji ${ }^{5}$.

Podejmując temat dotyczący regaliów akademickich oraz rytuałów i porządku panującego podczas ceremonii nadania stopni i tytułów naukowych, nie sposób nie zwrócić uwagi na paralelizm tej rzeczywistości z wieloma innymi kontekstami i wymiarami życia społecznego, w których bezwzględne przestrzeganie obowiązujących zasad i akceptacja tradycyjnych zaleceń,

\footnotetext{
${ }^{1}$ J. Verger, Doctor, doctoratus, [w:] Lexikon des Mittelalters, 3, Stuttgart 1999, s. 1155-1156.

2 E. Szymczak, Promocje doktorskie jako ceremonie akademickie, Studia Edukacyjne, 2018, 48, s. 217.

3 Tamże.

${ }^{4}$ Degree Ceremony. University of Oxford, źródło: https://www.ox.ac.uk/media/global/ wwwoxacuk/localsites/studentgateway/documents/Degree_Ceremony_Brochure.pdf, [dostęp: 15.10.2018].

5 J. Verger, Doctor, doctoratus, s. 1155-1156.
} 
obrzędów i rytuałów staje się ich nieodłącznym elementem, wpisującym się w logikę określonej rzeczywistości społecznej. Dlatego też, pozwolę sobie na odniesienie tego zagadnienia i przyrównanie go do kilku innych przestrzeni społecznych związanych z sądownictwem - kategorią prawa, służbą zdrowia, czy służbami mundurowymi, a także na wyodrębnienie kilku takich elementów szczegółowych, jak: warstwa performatywna (a w niej wygląd zewnętrzny i symbole), kategoria solidarności grupowej oraz emocjonalnej przynależności - a wszystko w ramach konstruowania indywidualnej i kolektywnej tożsamości.

Okazuje się, iż ogólne funkcje rytuału ujawniają jego oczywiste podobieństwo do prawa. Rytuał rozumiany jest jako skonwencjonalizowana ceremonia. Ta z kolei odnosi się do wydarzenia o charakterze rytualnym, zorganizowanego na rzecz wyjątkowej okazji ${ }^{6}$. Zarówno ceremonie, jak i związane z nimi rytuały występują niemalże we wszystkich kulturach (mam na myśli m.in. ceremonie śmierci, narodzin, uzdrowienia, małżeństwa, czy też rytuały religijne), a ich historia oraz czas praktykowania sięga niekiedy dziesiątków tysięcy lat. Pozwalają one na wybrzmienie ważnych dla społeczeństwa wartości (poprzez obecność konkretnych symboli), wywołują emocje oraz stanowią formę prezentującą konkretną grupę społeczną7.

Pierwszym przykładem, który potwierdza występowanie pewnych cech wspólnych w zakresie zachowania ciągłości tradycji (co w środowisku uniwersyteckim ma swoje urzeczywistnienie w obecności akademickich symboli, stanowiących dziś pewien jednoznacznie dookreślony wyznacznik w zakresie tego, jak winny przebiegać i wyglądać akademickie uroczystości), mogą być ceremonialne praktyki sądowe. Świadczy o tym między innymi sam przebieg procesu, układ przestrzeni i elementów znajdujących się w wyposażeniu sali sądowej, strój sędziego, obecne regalia (toga, łańcuch), a także specyficzny, prawniczy język czy niezmienne w swym brzmieniu frazy wypowiadane $\mathrm{w}$ toku procesu sądowego (np. związane z przedstawieniem wyroku i zamknięciem postępowania). Przejrzystość, bezwzględność i nieodwołalność oraz wszelkie kwestie proceduralne charakterystyczne dla tej przestrzeni przyczyniają się do kształtowania profesjonalnego wizerunku instytucji sądowych, sprzyjają poszanowaniu praworządności oraz pozytywnej ocenie całego procesu sądowego ${ }^{8}$. Pojawia się zatem pytanie,

${ }^{6}$ L. Grimes Ronald, Ritual, [w:] Guide to the study of religion, red. W. Braun, Continuum International Publishing Group, 2000, s. 260.

${ }^{7}$ K. Allan, Contemporary Social \& Sociological Theory. Visualising Social Worlds, Third Edition, USA 2013, s. 125.

${ }^{8}$ O.G. Chase, J. Thong, J. Judges, The Effect of Courtroom Ceremony on Participant Evaluation of Process Fairness-Related Factors, Yale Journal of Law \& the Humanities, 2012, 24, 1, Article 10, s. 221. 
czy ceremonialne praktyki obecne $\mathrm{w}$ środowisku akademickim $\mathrm{w}$ podobny sposób mają za zadanie wpłynąć na pozytywną ocenę ukończonej uczelni, jak również zwiększyć satysfakcję absolwentów z powodu (wysoce zadowalającego) ukończenia studiów oraz podnieść społeczną i utylitarną rangę tytułu lub stopnia, który uzyskaliśmy w toku edukacji na studiach wyższych, czy też w trakcie pokonywania kolejnych szczebli kariery naukowej? ${ }^{9}$

Wydaje się, iż mogą stanowić one - poprzez charakter tego typu wydarzeń oraz niezmienne od lat etapy jego przebiegu czy wykorzystywane zwroty i formuły (np. w języku łacińskim, co ma miejsce m.in. na niwersytecie w Oxfrodzie ${ }^{10}$ ), a także znaczenie kolorów (dla przykładu zgodnie z akademickim kodeksem kostiumowym stworzonym w 1895 roku w Stanach Zjednoczonych - kolory kapturów różnią się od ukończonego kierunku, uzyskanego stopnia oraz uczelni i kraju ${ }^{11}$, wyjątkowość strojów i obecność pewnych regaliów (jak np. biret, toga i kaptur ${ }^{12}$ ) - jednoznaczne uzasadnienie uzyskanej pozycji i związanego z nią prestiżu. Obydwa przykłady, choć odnoszące się do całkiem odmiennych środowisk, mogą stanowić z jednej strony bezsprzeczne potwierdzenie, ale też podkreślenie posiadanych kompetencji (sędziego czy też władz uniwersyteckich i w końcu samego absolwenta uczelni) i podniesienie obecnych $\mathrm{w}$ danej przestrzeni wartości (dowodząc o obiektywności i sprawiedliwości wyroku sądu, czy odnosząc się do wartości kryjących się za przyznanym tytułem i stopniem naukowym oraz związanych $\mathrm{z}$ osiągnięciem pewnego poziomu naukowego wtajemniczenia). Z drugiej jednak strony nie stanowią już one - odnosząc się do współczesnej rzeczywistości uniwersyteckiej, a w niej umasowienia szkolnictwa wyższego oraz inflacji dyplomów ${ }^{13}$ - jednoznacznego zapewnienia o uzyskaniu wysokopłatnej pracy, objęciu satysfakcjonującego stanowiska w przestrzeni zawodowej, czyli mówiąc szerzej - o sukcesie życiowym, naukowym i społecznym. Zatem, w przypadku środowiska akademickiego, biorąc pod uwagę perspektywy absolwenta uczelni uzyskującego dyplom ukończenia studiów wyższych, można odnieść wrażenie niespójności formy, warstwy performatywnej, przebiegu ceremonii akademickiej, do rze-

\footnotetext{
${ }_{9}$ E. Szymczak, Promocje doktorskie, s. 218.

${ }^{10}$ Degree Ceremony. University of Oxford, źródło: https://www.ox.ac.uk/media/global/ wwwoxacuk/localsites/studentgateway/documents/Degree_Ceremony_Brochure.pdf, [dostęp: 15.10.2018].

${ }^{11}$ Academic Regalia, Academic Ceremony Guide, American Council on Education, źródto: http:/ / www.acenet.edu/news-room/Pages/Academic-Ceremony-Guide.aspx, [dostęp: 15.10.2018].

${ }^{12}$ Kaptury związane są z Hooding ceremonies - ceremoniami zakapturzenia, które mają długą tradycję w Stanach Zjednoczonych. Są one przeprowadzane przez poszczególne szkoły wyższe, aby wyróżnić i zaprezentować studentów, którzy uzyskali tytuł lub stopień naukowy (np. ukończyli studia magisterskie lub studia doktoranckie).

${ }_{13}$ Z. Melosik, Uniwersytet i społeczeństwo. Dyskursy wolności, wiedzy i władzy, Kraków 2009, s. 135.
} 
czywistej mocy sprawczej kredencjału (oczywiście nie jest to regułą, czego potwierdzeniem mogą być dyplomy prestiżowych i elitarnych uniwersytetów, takich jak np. Harvard University, Oxford University, University of Cambridge, czy Stanford University ${ }^{14}$ i wielu innych, których dyplom w dalszym ciągu stanowi wysoką wartość na rynku pracy oraz swoiste potwierdzenie posiadania odpowiednio wysokiego kapitału kulturowego, jak i uzyskania cenionych w społeczeństwie kompetencji i kwalifikacji $)^{15}$.

Porównując obydwie wyżej wymienione przestrzenie oraz obowiązujące $w$ nich symbole, ceremonie i obrzędy, okazuje się - odnosząc się w pierwszej kolejności do rzeczywistości prawniczej - iż nie bez znaczenia jest również sam wygląd sędziego i noszone przez niego regalia. $\mathrm{Na}$ przykład, sędzia federalny Jerome Frank, na którego powołuje się w swoim artykule Oscar G. Chase i Jonathan Thong, zwraca uwagę, iż strój sędziego może spełniać trzy funkcje. Po pierwsze, może zwiększyć prestiż sędziego i tym samym szacunek dla władzy sądowniczej. Podążając tym sposobem myślenia, można uznać, iż jednolity wygląd sędziów może także promować ideę sprawiedliwości (stanowić swoistego rodzaju "mundur" - jak w przypadku osób pracujących w różnego rodzaju służbach z ramienia Ministerstwa Spraw Wewnętrznych i Administracji czy Ministerstwa Obrony Narodowej) i przyczyniać się do zwiększenia szacunku wobec "rządów prawa”. Kolejną kwestią jest fakt, iż strój sędziego stanowi przykład „nieszkodliwej relikwii”, która nie ma wpływu na nikogo i jest związana wyłącznie z tradycją. Można zatem wyodrębnić trzy konteksty: prestiż, szacunek i tradycję. $\mathrm{Z}$ jednej strony mogą one zwiększać wartość osoby piastującej dany urząd czy stanowiącej przedstawiciela pewnej profesji, zawodu - podkreślając jego rangę, z drugiej jednak okazuje się, iż strój ten może niekiedy przyczynić się do potęgowania poczucia "niepokoju” wśród osób, którym przyszło się z nimi w określonym kontekście społecznym zmierzyć, zetknąć. Jest to szczególnie widoczne w sytuacji zderzenia się danej osoby z gronem prawników, stronami postępowania i świadkami (np. w toku danej sprawy sądowej czy szerzej - o charakterze prawnym). Formalny strój może z jednej strony mieć wpływ na ogólną satysfakcję i poczucie komfortu jednostki (przekonanie o zetknięciu się z kompetentną, rzetelną i uczciwą osobą), ale również może wpłynąć na udzielane przez nią odpowiedzi, dokonywanie retrospekcji i ustalanie ważnych dla postępowania faktów (za sprawą dzielącego obie jednostki dystansu, niemalże samoistnie tworzącej się hierarchii

${ }^{14}$ A. Gromkowska-Melosik, Globalne rankingi uniwersytetów i akademicka gra o status, Studia Edukacyjne, 2015, 37, s. 14-15.

15 A. Gromkowska-Melosik, Eton College. Szkic do portretu brytyjskiej elitarnej edukacji, Studia Edukacyjne, 2014, 30, s. 50. 
oraz doniosłego, formalnego charakteru wzajemnych kontaktów $)^{16}$. I znów pojawia się pytanie, czy te same funkcje może spełniać uroczystość wręczenia dyplomów - absolutorium bądź ceremonia okrycia Hooding Ceremonie (charakterystyczna dla wielu uczelni wyższych w Stanach Zjednoczonych), podczas której również w dużym stopniu kładzie się nacisk na wygląd osób biorących udział w tym wydarzeniu (zarówno władz uczelni - osób zasiadających przy stole prezydialnym oraz absolwentów) i bezwzględną obecność - spełniających jasno określone funkcje - akademickich regaliów (jak np. toga i biret)? Być może ceremonialne praktyki bez względu na miejsce i środowisko ich stosowania w sposób symboliczny decydują o autorytecie i randze danej instytucji, a egzekwowanie związanych z nimi rytuałów i regaliów sprzyja budowaniu pozytywnego wizerunku i zaufania publicznego, zwiększając tym samym prestiż, szacunek i znaczenie danej przestrzeni społecznej.

Biorąc pod uwagę powyższe fakty oraz odnosząc je do rzeczywistości uniwersyteckiej należy stwierdzić, iż długa historia promocji akademickich i związanych z nimi ceremonii, a także bezwzględne przepisy obejmujące konkretne nakazy dotyczące wyglądu osób biorących udział w tym wydarzeniu (łącznie z jasno wyartykułowanymi zaleceniami dotyczącymi stroju założonego pod togą, a nawet koloru i stanu noszonego obuwia) mogą do pewnego stopnia stanowić potwierdzenie relacji władzy i dominacji w strukturze uniwersyteckiej, które w tym wymiarze - odnosząc się do wydarzeń o charakterze ceremonialnym - w dużym stopniu koncentrują się wyłącznie wokół warstwy performatywnej i dotyczą ściśle określonego wizerunku.

Nie sposób w tym kontekście nie zatrzymać się więc na zagadnieniu dotyczącym mody, kwestii związanych z wizerunkiem jednostki oraz relacji władzy działającej na mikropoziomie ciała. Zbyszko Melosik nawiązując do społecznych kontekstów ciała, twierdzi, że współcześnie ciało „staje się tekstem, w który wpisywane są różne konfiguracje społecznie konstruowanych znaczeń" ${ }^{\prime 17}$. Wiedza o ciele i sposobach jego klasyfikowania przybiera charakter dyscyplinujący jednostkę i jej tożsamość, w trosce o dostosowywanie jej do powszechnie obowiązujących norm i cieszących się największą akceptacją społeczną dyskursów. Oczywiście, nie odbywa się w to w sposób jawny i radykalny - owa władza ma charakter subtelny, rozproszony i niejednokrotnie niewidzialny. Wydawać by się mogło, iż z pozoru nie ingeruje ona znacząco w życie jednostki, jednak wymusza (pod pozorem wolności jednostki) pewne zachowania i sposoby wyrażania siebie oraz swojego ciała zgodnie z akcep-

\footnotetext{
${ }^{16}$ O.G. Chase, J. Thong, J. Judges, The Effect of Courtroom Ceremony, s. 211-212.

17 Z. Melosik, Tożsamość ciało i władza w kulturze instant, , Kraków 2010, s. 11.
} 
towalnymi normami i w związku ze społeczną presją wywieraną w tym wymiarze, stanowiąc swoistą formę kontroli (człowieka i tożsamości) ${ }^{18}$. W kontekście realizowanego tematu dyscyplinowanie ciała ma co prawda charakter incydentalny o ściśle określonych ramach czasowych (tj. ma miejsce głównie podczas trwania uroczystości), jednak zdaje się również potwierdzać uwikłanie jednostki w sieć społecznie skonstruowanych znaczeń, symboli i wiedzy, która w danej przestrzeni społecznej uzyskuje status dominującej (a więc obiektywnej i uniwersalnej) ${ }^{19}$.

Bezsprzecznie, na pierwszy plan, podczas analizowania tego zagadnienia, wysuwa się kwestia relacji władzy i dominacji oraz kategoria prawa. Mając na uwadze konwencjonalność warstwy ekspresyjnej ${ }^{20}$ oraz obowiązkowy charakter wydarzeń o charakterze ceremonialnym, można uznać, iż stanowią one, również poprzez budowanie poczucia solidarności grupowej, nieodłączny element rzeczywistości społecznej ${ }^{21}$. Warto zwrócić uwagę, iż - odnosząc się do przywołanej definicji - również prawo sprzyja poczuciu solidarności jednostki z grupą oraz narzuca pewne sposoby definiowania rzeczywistości i zasady funkcjonowania w określonej przestrzeni społecznej, co także ma charakter konwencjonalny. Zarówno więc rytuały, jak i prawo przypominają normy społeczne - dookreślają i definiują formy, postawy, zachowania, które są egzekwowane. Można je podzielić na mieszczące się w normie i stanowiące jej przekroczenie - to jest nieprzestrzeganie wspólnych zaleceń i praw, czego reperkusją może być nałożenie sankcji (czy to w postaci grzywny i odpowiedzialności karnej, czy też niemożności wzięcia udziału w ceremonii z powodu np. nieodpowiedniego stroju lub prezentowanej postawy społecznej). Obydwa pojęcia są związane z dyscyplinowaniem zachowania jednostki i wpływają - $w$ relatywnym tego słowa znaczeniu i wymiarze - na jej życie i sposób funkcjonowania, stanowiąc swoisty mechanizm społecznej kontroli (w wymiarze mikro- lub makrospołecznym) ${ }^{22}$. Można dojść do wniosku, iż jednostki zwykle dostosowują się do obowiązujących w danej przestrzeni społecznej norm (czy to w kontekście prawnym, czy też odnosząc się do obowiązujących i akceptowalnych $w$ danej przestrzeni społecznej - np. uniwersyteckiej - zachowań) z powodu chęci potwierdzenia swojej przynależności do określonej grupy społecznej, której czują się częścią. Potwierdzeniem tego sposobu myślenia, u źródeł którego leży kwestia społecznej identyfikacji oraz wymiar solidarności grupowej, są wnioski takich badaczy, jak na przy-

\footnotetext{
18 Tamże, s. 11-17.

19 Tamże, s. 11-13.

${ }^{20}$ C. Bell, Ritual theory, ritual practice, New York - Oxford 1992, s. 19.

${ }^{21}$ V. Turner, The ritual process: structure and anti-structure, New York 1991.

${ }^{22}$ G.P. Miller, The legal function of ritual, s. 1181, źródło: http://studentorgs.kentlaw.iit. edu/cklawreview/wp-content/uploads/sites/3/vol80no3/Miller.pdf, [dostęp: 15.10.2018].
} 
kład: Dan Kahan ${ }^{23}$, Lawrence Lessig ${ }^{24}$, Richard McAdams ${ }^{25}$ oraz Eric Posner ${ }^{26}$. Zwracali oni uwagę, iż ludzie w dużym stopniu mogą czuć się zmotywowani do zachowania w określony sposób, jednak nie z powodu nałożenia sankcji, czy też realnej groźby o charakterze formalnym, która może stanowić logiczną konsekwencję czynów dokonanych, niedokonanych bądź też niewłaściwie wykonanych, ale z powodu poczucia przynależności i związku z daną grupą społeczną. Szczególnie widoczne jest to w spójnych wewnętrznie społecznościach (ale nie tylko tam), gdzie interakcje ludzi są w dużej mierze powtarzalne. Wtedy to normy społeczne mogą dostarczyć skutecznych ram do podejmowania aktywności i działania, co z kolei pozwoli na zachowanie struktury społecznej oraz umożliwi kontrolę własnego zachowania ${ }^{27}$.

Można zatem wysunąć wniosek, iż wiele środowisk: akademickie, prawnicze, wojskowe, czy też lekarskie (w które doskonale wpisują się kategorie wiedzy, władzy i tworzone na ich podstawie dysproporcje $w$ relacjach interpersonalnych - np. lekarza z pacjentem, o czym traktuje m.in. Z. Melosik w książce zatytułowanej Kultura popularna i tożsamość młodzieży. W niewoli władzy $i$ wolności ${ }^{28}$ ) oraz ich wewnętrzne zasady funkcjonowania i regulacje prawne sprzyjają kreowaniu odpowiedniego wizerunku danej instytucji, stanowiąc element właściwej dla niej kultury organizacyjnej, w którą wpisane są relacje dominacji i władzy oraz określona hierarchia społeczna ${ }^{29}$. Jest to potwierdzone poprzez takie fakty, jak na przykład: charakterystyczne cechy architektoniczne budynku, w którym mieści się dana instytucja, właściwe dla niej elementy wystroju, układ pomieszczeń (ułożenie ławek, krzeseł, obecność podium), charakterystyczne formy tytularne oraz - wspomniany już odpowiedni strój ${ }^{30}$.

Warto zwrócić uwagę, że obok warstwy wizualnej niezwykle istotny jest w tym kontekście wymiar emocjonalny - im większe poczucie emocjonalnej

${ }^{23}$ D.M. Kahan, Social Meaning and the Economic Analysis of Crime, Journal of Legal Studies, 1998, 27, 3, Article 5, s. 609.

${ }^{24}$ L. Lessig, Social Meaning and Social Norms, 144 U. PA. L. REV. 2181 (1996), źródło: https:/ / dash.harvard.edu/bitstream/handle/1/12942289/Social\%20Meaning\%20and \%20Social\%20 Norms.pdf?sequence=1, [dostęp: 15.10.2018].

${ }^{25}$ R.H. McAdams, Cooperation and Conflict: The Economics of Group Status Production and Race Discrimination, 108 „Harvard Law Review” 1003 (1995), źródło: https://chicagounbound.uchicago.edu /cgi/viewcontent.cgi?article=2650\&context=journal_articles, [dostęp: 15.10.2018].

${ }^{26}$ E.A. Posner, Symbols, Signals, and Social Norms in Politics and the Law, The Journal of Legal Studies, 1998, 27, 2 , s. 765-797.

${ }_{27}$ G.P. Miller, Norms and Interests, Hofstra Law Review, 2003, 32, 2, Article 3, źródło: https://scholarlycommons.law.hofstra.edu/hlr/vol32/iss2/3, [dostęp: 15.10.2018].

${ }_{28}$ Z. Melosik, Kultura popularna i tożsamość młodzieży. W niewoli władzy i wolności, Kraków 2013, s. 363-376.

${ }^{29}$ P. Elsmore, Organizational culture: organizational change? New York 2018, s. 45.

${ }^{30}$ O.G. Chase, J. Thong, J. Judges, The Effect of Courtroom Ceremony, s. 224. 
przynależności, tym większy sens i zakres przynależności do grupy ${ }^{31}$. Z pojęciem tym związane jest pojęcie standardów moralnych. Okazuje się bowiem, iż osoby, które charakteryzuje solidarność grupowa mają wysokie poczucie odpowiedzialności etycznej i moralnej związanej z przekonaniem o zasadności i obowiązku dostosowywania się do powszechnie obowiązujących norm, wartości i zaleceń oraz kontrolowania swojego zachowania w imię poczucia solidarności z daną grupą społeczną ${ }^{32}$ (wyjątkiem, który potwierdza opisaną regułę, są organizacje o charakterze przestępczym czy gangi, w których co prawda solidarność grupowa odgrywa znaczącą rolę i stanowi fundament funkcjonowania takich społeczności, jednak kwestie dotyczące przestrzegania zasad etycznych i moralnych nie są w tym środowisku skorelowane z powszechnie obowiązującym kodeksem etycznym. Niniejsze społeczności charakteryzuje bowiem specyficzna struktura i właściwy dla nich kodeks postępowania oraz egzekwowania przynależności do grupy. Nie zmienia to jednak faktu, iż mają one wewnętrznie spójny system znaczeń i wartości, w których mieści się np. kategoria lojalności). Standardy moralności, to nic innego jak na przykład: wzorce komunikacyjne (odpowiednie zwroty i sformułowania - swoisty kod komunikacyjny, przywołując pojęcie analizowane przez Basila Bernsteina, który stanowi czynnik spajający i identyfikacyjny ${ }^{33}$ ), styl ubierania się oraz rygorystyczne reguły wejścia i wyjścia (nie jest łatwo zarówno być przyjętym do danej społeczności, jak i być z danej grupy wykluczonym $)^{34}$. Podobnie rzecz wygląda w przypadku społeczności akademickich, jak i samych ceremonii nadania stopni oraz tytułów naukowych. Niejednokrotnie przy okazji wielu wydarzeń, między innymi promocji doktorskich, zwraca się uwagę na specyfikę środowiska akademickiego, jego integralność oraz konieczność spełnienia jasno sprecyzowanych zaleceń i warunków, by móc stać się jego częścią. Nie powinien zatem dziwić fakt obecności (m.in. w przestrzeni Internetu) rozlicznych przykładów, tekstów, prezentacji, czy filmów instruktażowych, które mają na celu w odpowiedni sposób przygotować uczestników ceremonii wręczenia dyplomów do tego wydarzenia oraz szczegółowo wyjaśnić wszystkie zasady, normy, jak też obowiązujące symbole i wynikające z nich zachowania.

Rytuały ilustrują sposób, w jaki pewne wydarzenia, sytuacje powinny być przeżywane i wykonywane, a tym samym dostarczają ram moralności, które pomagają ludziom zrozumieć ich własne życie. Postrzeganie świata przez pryzmat ram moralnych pozwala ludziom na doświadczanie przypisanych im ról oraz wykonywanych zadań jako sprawiedliwych i właściwych. Ak-

\footnotetext{
${ }^{31}$ K. Allan, Contemporary Social, s. 125.

32 Tamże.

${ }^{33}$ B. Bernstein, Class, codes and Control, volume 1, London 2003.

${ }^{34}$ K. Allan, Contemporary Social, s. 125.
} 
tywność uczestników oraz fakt, iż są oni częścią wydarzenia i biorą w nim czynny udział (nie stanowią grupy biernych obserwatorów) sprawia, że istnieje możliwość utraty dystansu do jego przebiegu. Uczestnicy tego typu wydarzeń niejednokrotnie czują się odpowiedzialni za przebieg ceremonii i sukces rytuału, co może świadczyć do pewnego stopnia o ich identyfikacji z rytuałem oraz akceptacji ról społecznych wpisanych w konwencję ceremonii i przypisanych poszczególnym jej uczestnikom. Biorąc pod uwagę warstwę performatywną, można stwierdzić, iż rytuały, oraz wszelkie wydarzenia o takim charakterze, mają za zadanie przykuwać społeczną uwagę, jak również tworzyć wspólny emocjonalny nastrój i swoisty klimat takiego wydarzenia $^{35}$. Jest to możliwe poprzez stosowanie takich zabiegów, jak: muzyka, cisza, hipnotyczne intonacje oraz zsynchronizowane działania i bezwzględny nacisk na precyzję (czego potwierdzeniem - w przypadku promocji akademickich - są liczne próby i długotrwałe przygotowanie do tego momentu). Jak już zostało wspomniane, kolejnym istotnym elementem jest przestrzeń. Architektura rytuału może działać jako „soczewka ogniskująca”, ustanawiając możliwość nadawania znaczeń poprzez „reżyserowanie” i koncentrowanie uwagi na określonych elementach (zawiera cały wachlarz czynników o charakterze sensorycznym i poznawczym oraz liczne strategie komunikacyjne, które mają na celu zaktywizować uczestników i skłonić do funkcjonowania w określony sposób. Zalicza się do nich m.in. kostiumy, opowiadania, procesje, oświetlenie, przemówienia, zapach, śpiew, poezję, piosenki, dotyk, widowiskowość, symbolizm) ${ }^{36}$.

Rytuały podkreślając to, czego nie wolno zrobić, wymagają od uczestników zwiększonej koncentracji na ich zachowaniu (jednostki wstają, siadają, maszerują, wygłaszają w jednym czasie takie same formuły, wykonują w określony sposób jednoznacznie sprecyzowane gesty itp.). Okazuje się, iż nawet pozornie irracjonalny lub nonsensowny aspekt rytuałów i związane z nim zachowanie, symbole czy gesty, może skupiać uwagę i niejako wymuszać maksymalne skoncentrowanie i skupienie jednostki (z powodu lęku bądź niechęci związanej z niedostosowaniem się do zewnętrznych zaleceń i panujących reguł) ${ }^{37}$. Niejednokrotnie, na co zwraca uwagę G.P. Miller, uczestnicy stają się „całkowicie zanurzeni we właściwe wykonywanie złożonych zadań" ${ }^{38}$.

Biorąc pod uwage przywołane argumenty, można stwierdzić, iż rytuały kształtują tożsamość jednostki. Mogą stanowić nie tylko tymczasowe dozna-

\footnotetext{
${ }^{35}$ Tamże.

${ }^{36}$ G.P. Miller, The legal function of ritual, s. 1190.

${ }^{37}$ F. Staal, The Meaninglessness of Ritual, Numen, 1979, 26, 1, s. 2-22.

${ }^{38}$ G.P. Miller, The legal function of ritual, s. 1190.
} 
nie o określonym zabarwieniu emocjonalnym, jak również formę oczyszczenia (katharsis), ale też mogą być uznane za stały czynnik zmiany polegający na dostosowywaniu tożsamości do społecznych oczekiwań w wymiarze właściwego postępowania. W konsekwencji, ludzie spełniają nie tylko oczekiwania społeczne zakodowane $\mathrm{w}$ rytuale polegające na unikaniu sankcji, ale także zaczynają funkcjonować w odpowiedni sposób, zgodnie z rolą, jaka została im przypisana. W sytuacji, kiedy nie będą zachowywać się zgodnie z rolą, mogą odczuwać szereg emocji sygnalizujących swoiste naruszenie tożsamości, jak na przykład: poczucie winy, niepokój, wstyd, niesmak, przerażenie. W celu uniknięcia tychże negatywnych uczuć pozostaje im dostosowywanie własnych zachowań do tych, jakie wyznacza określona, przypisana im rola społeczna ${ }^{39}$. Jest to związane z przywołanym już pojęciem solidarności grupowej, która - odwołując się do definicji Kennetha Allana - odnosi się do poczucia wspólnotowości i przekonania, że jest się elementem większej zbiorowości. Ceremonie akademickie, a wśród nich uroczystości nadania stopni lub tytułów naukowych, stanowią potwierdzenie społecznej przynależności jednostki oraz pełnią funkcję identyfikacyjną - nie tylko na czas trwania konwencjonalnych rytuałów, ale rozciągającą się na całe życie jednostki, czego potwierdzeniem jest - w głównej mierze - uzyskany status społeczny wraz z całym wachlarzem charakterystycznych dlań cech i sposobów zachowania.

Powyższa argumentacja miała na celu ukazanie wielowymiarowości pojęcia kryjącego się pod hasłem „ceremonia”. Stanowi ona przykład oraz swoiste potwierdzenie - bez względu społeczny wymiar oraz kontekst prowadzonych analiz - niezwykłej rangi, doniosłości oraz wyjątkowości sytuacji ${ }^{40}$, która - jak się okazuje - nie może obyć się bez egzekwowania znajomości rytuałów, symboli oraz poprawnego ich odczytywania i stosowania. W obliczu powyższych twierdzeń można dokonać próby odpowiedzi na pytanie, na ile uroczystości o charakterze ceremonialnym stanowią wartość autoteliczną (samą w sobie), a na ile instrumentalną ${ }^{41}$. Do którego stopnia można zgodzić się z poglądem, iż skupiają się one wyłącznie na koncentracji i trosce o odpowiedni kształt i formę wydarzenia - pozostając wyłącznie w warstwie performatywnej, wizualnej (która - w myśl przywołanej definicji - stanowi fundament tychże działań), a na ile mamy już do czynienia $\mathrm{z}$ instrumentalnym i intencjonalnie skonstruowanym procesem nadawania odpowiednio

39 Tamże.

${ }^{40}$ J. Tinson, P. Nuttall, Exploring appropriation of global cultural rituals, [w:] Multicultural Perspectives in Customer Behaviour, red. M.G. Piacentini, Ch.C. Cui, New York 2012, s. 81.

${ }^{41}$ S.F. Moore, B.G. Myerhoff, Secular Ritual: Forms and Meanings, [w:] Secular Ritual, red. S.F. Moore, B.G. Myerhoff, The Netherlands 1977, s. 5. 
przypisanych znaczeń wpisanych $\mathrm{w}$ repertuar kulturowy danej organizacji ${ }^{42}$ (w myśl teorii tekstów kulturowych i sposobów ich odczytywania według Stuarta Halla ${ }^{43}$ ) w celu wywarcia odpowiedniego wrażenia i w konsekwencji uzyskania określonych rezultatów (związanych z relacjami władzy i dominacji, praktykami dyscyplinującymi jednostkę i jej ciało oraz kwestią dotyczącą kontrolowanej modyfikacji naszej tożsamości)? Wyrażam nadzieję, że to pytanie stanie się przyczynkiem do dokonywania kolejnych analiz i refleksji wokół niniejszego zagadnienia w relacji do różnych wymiarów i obszarów życia społeczno-kulturowego w przyszłości.

\section{BIBLIOGRAFIA}

Allan K., Contemporary Social \& Sociological Theory. Visualising Social Worlds, Third Edition, USA 2013.

Academic Regalia, Academic Ceremony Guide, American Council on Education, źródto: http: //www.acenet.edu/news-room/Pages/Academic-Ceremony-Guide.aspx, [dostęp: 15.10.2018].

Bell C., Ritual theory, ritual practice, Oxford University Press, New York - Oxford 1992.

Bernstein B., Class, codes and Control, volume 1, Routledge, London 2003.

Chase O.G., Thong J., Judges J., The Effect of Courtroom Ceremony on Participant Evaluation of Process Fairness-Related Factors, Yale Journal of Law \& the Humanities, 2012, 24, 1, Article 10.

Degree Ceremony. University of Oxford, źródto: https://www.ox.ac.uk/media/global/wwwoxacuk/localsites/studentgateway/documents/Degree_Ceremony_Brochure.pdf, [dostęp: 15.10.2018].

Dorleijn G.J., Vanstiphout H.L.J. (red.), Cultural Repertoires. Structure, Function, Dynamics, Petters, Leuven-Paris-Dudley-MA 2003.

Elsmore P., Organizational culture: organizational change? Routledge Revivals, New York 2018.

Grimes Ronald L., Ritual, [w:] Guide to the study of religion, red. W. Braun, Continuum International Publishing Group, 2000.

Gromkowska-Melosik A., Eton College. Szkic do portretu brytyjskiej elitarnej edukacji, Studia Edukacyjne, 2014, 30.

Gromkowska-Melosik A., Globalne rankingi uniwersytetów i akademicka gra o status, Studia Edukacyjne, 2015, 37.

Hall S., Kodowanie i dekodowanie, Przekazy i Opinie, 1987, 1-2.

Kahan D.M., Social Meaning and the Economic Analysis of Crime, Journal of Legal Studies, 1998, 27, 3, Article 5.

Lessig L., Social Meaning and Social Norms, 144 U. PA. L. REV. 2181 (1996), źródło:https: / / dash.harvard.edu/bitstream/handle/1/12942289/Social\%20Meaning\%20and\%20 Social\%20Norms.pdf?sequence=1, [dostęp: 15.10.2018].

${ }^{42}$ G.J. Dorleijn, H.L.J. Vanstiphout (red.), Cultural Repertoires. Structure, Function, Dynamics,

Petters, Leuven-Paris-Dudley-MA 2003, s. 12.

${ }^{43}$ S. Hall, Kodowanie i dekodowanie, Przekazy i Opinie, 1987, 1-2, s. 58-71. 
McAdams R.H., Cooperation and Conflict: The Economics of Group Status Production and Race Discrimination, 108 „Harvard Law Review” 1003 (1995), źródło: https://chicagounbound.uchicago.edu/cgi/viewcontent.cgi?article=2650\&context=journal_articles [dostęp: 15.10.2018].

Melosik Z., Uniwersytet i społeczeństwo. Dyskursy wolności, wiedzy i władzy, Oficyna Wydawnicza Impuls, Kraków 2009.

Melosik Z., Tożsamość, ciało i władza w kulturze instant, Oficyna Wydawnicza Impuls, Kraków 2010.

Melosik Z., Kultura popularna i tożsamość młodzieży. W niewoli władzy i wolności, Oficyna Wydawnicza Impuls, Kraków 2013.

Miller G.P., Norms and Interests, Hofstra Law Review, 2003, 32, 2, Article 3, źródło: https:/ / scholarlycommons.law.hofstra.edu/hlr/vol32/iss2/3, [dostęp: 15.10.2018].

Miller G.P., The legal function of ritual, źródło: http:/ / studentorgs.kentlaw.iit.edu/cklawreview/wp-content/uploads/sites/3/vol80no3/ Miller.pdf, [dostęp: 15.10.2018].

Moore S.F., Myerhoff B.G., Secular Ritual: Forms and Meanings, [w:] Secular Ritual, red. S.F. Moore, B.G. Myerhoff, Van Gorcum, The Netherlands 1977.

Posner E.A., Symbols, Signals, and Social Norms in Politics and the Law, The Journal of Legal Studies, 1998, 27, 2.

Staal F., The Meaninglessness of Ritual, Numen, 1979, 26, 1.

Szymczak E., Promocje doktorskie jako ceremonie akademickie, Studia Edukacyjne, 2018, 48.

Tinson J., Nuttall P, Exploring appropriation of global cultural rituals, [w:] Multicultural Perspectives in Customer Behaviour, red. M.G. Piacentini, Ch.C. Cui, Routledge, New York 2012.

Turner V., The ritual process: structure and anti-structure, New York 1991.

Verger J., Doctor, doctoratus, [w:] Lexikon des Mittelalters, 3, J.B. Metzler, Stuttgart 1999. 